\title{
Study of Surface Water and Soil Quality Affected by Heavy Metals of Pabna Sadar
}

\author{
M. S. Sultana ${ }^{a}$, M. S. Islam ${ }^{\text {* }}$, S. Rahman ${ }^{a}$ and M. A. Al-Mansur ${ }^{b}$ \\ ${ }^{a}$ Department of Environmental Sciences, Jahangirnagar University, Savar, Dhaka. ${ }^{b}$ Analytical Research \\ Division, Bangladesh Council of Scientific and Industrial Research (BCSIR) Laboratories, Dhaka.
}

\begin{abstract}
Concentrations of heavy metals such as $\mathrm{As}, \mathrm{Cd}, \mathrm{Co}, \mathrm{Cr}, \mathrm{Ni}, \mathrm{Fe}, \mathrm{Zn}, \mathrm{Pb}, \mathrm{Hg}$ and $\mathrm{Cu}$ in surface water and soils were determined by using Atomic Absorption Spectrophotometer (AAS) using standard analytical methods. The physicochemical and anionic properties of the surface water were also determined to assess the pollution level of this area. The results reveal that although few parameters of the surface water are within the standard value but most of the physicochemical and anionic parameters such as $\mathrm{BOD}, \mathrm{COD}, \mathrm{F}^{-}, \mathrm{NO}_{3}{ }^{-}, \mathrm{NH}_{3}$ and $\mathrm{Pb}$ of the surface water are significantly higher than the standard for drinking water. The result suggests that the surface water of this area is polluted by various pollutants and harmful for drinking and recreational purposes. Most of the soil contains much higher values of heavy metals like $\mathrm{Hg}, \mathrm{Mn}, \mathrm{Co}$ and $\mathrm{Zn}$ than world wide average soil values $(0.05,270.00,5.50,45.00 \mathrm{ppm}$ respectively). Therefore, it might have considerable negative effects on the soil quality, agricultural crops of the area and thus harmful for human health. Their higher concentration suggests that they resulted due to both natural origin and anthropogenic activities like, application of pesticides, mineral fertilization and industrial discharge.
\end{abstract}

Keywords: Heavy metals, Physicochemical properties, Surface water soil quality, Human health.

\section{Introduction}

In developing tropical countries like Bangladesh metal contamination has a significant impact on environmental health. Surface water bodies through out Bangladesh are also subject to potential water-quality hazards associated with metals due to both intense chemical weathering and anthropogenic activities (Islam et al.,2000). The major problems associated with excessive release of metals into the environment are that metals neither biodegradable, nor they are eliminated by incineration processes. These elements tend to persistent pollutants, and can accumulate in ecosystems and food chains. In addition, each metal has a specific chemical form (speciation) which determines its solubility in water, and consequently its ability to incorporate into biological systems. Organometallic compounds are able to pass through biological membranes because of their high degree of lipophilicity. Heavy metals like $\mathrm{Cd}, \mathrm{Cu}, \mathrm{Ni}, \mathrm{Hg}, \mathrm{Pb}$, and $\mathrm{Zn}$ represent potential hazards to plants and animals (Greenland et al.,1981).

Modern civilization is now dependent on the large-scale use of a wide range of metals and most of them are naturally present only at trace levels in the hydrosphere (biosphere) (Chow, 1968). A major route by which trace elements are dispersed in the hydrosphere (biosphere) is associated with the disposal of metal containing industrial effluents.

\footnotetext{
* Corresponding author: E-mail: sislama@hotmail.com
}

Industrial effluents discharged directly into the sea or into waterways or sewers, but whatever the disposal route, they constitute an important source of metals contaminating the environment. (Park, 1972, Chunye et al.,2008 ). Behaviour of trace metals in soil depends upon complex reactions among micro and macro cations and anions and different components of various soil phases, solid, aqueous and gaseous. Soils of several regions of the world have been subjected and will be in the future to mineral fertilization, pesticide application, and industrial pollution and, waste disposal. All these activities will affect both chemical and physical soil properties \& will lead to changes in the behaviour of trace element in soils (Salmons et al., 1995, Panichayapichet et al., 2007).

Reliable analytical methods play an extremely important role in monitoring the content of heavy metals in soil. Recently, atomic absorption spectrophotometric methods, anodic and cathodic stripping voltametric method, ICP spectrometry, Instrumental neutron activation analysis and X-ray fluorescence spectrometry for the determination of soils have been used (Brenner, 1998). No systematic work has been carried out to date to asses the possibility of metal contamination of surface waters in the northern region of Bangladesh. There are many industries (BSCIC, pharmaceutical, toiletries) 
situated in Pabna Sadar area, so many pollutants are continuously discharging to the surrounding areas. People who live surrounding area utilizing surface water for their house hold work, bathing, irrigation, fish culture and other necessary works.

Although the level of heavy metals in few selected areas of Bangladesh have been found in the literatures (Chamon et al.,2009, Shamshad et al., 2005, Sultana et al., 2009 \& 2003, Ali et al. 1998, Kashem et al., 1998, Alam et al. 2002, Mahfuz et al., 2004), but no systematic work about it has done at Pabna Sadar. So it is necessary to assess the soil and water quality of this area to concern people as well as to protect environment. So the purpose of this study was to determine the concentration of physicochemical properties and heavy metals in surface water and soil in order to asses the extent of pollution level of this area by comparing the surface water data of the study area with DoE standard for drinking water. Further the data of the studied soil was compared with average data for world wide soil and other areas soil of Bangladesh.

\section{Materials and Methods}

\section{Study Area}

Pabna Sadar is an upazila of Pabna district in the division of Rajshahi, Bangladesh (Fig.l). It is located at latitude $24.00^{\circ} \mathrm{N}$ and longitude $89.25^{\circ} \mathrm{E}$, has a tropical environment. It has an area of $443.90 \mathrm{sq} \mathrm{km}$, which is bounded by Atgharia and Iishwardi upazilas on the north, Kushtia sadar, Kumarkhali, Khoksa and Pangsha upazilas on the south, Santhia and Sujanagar upazilas on the east, Ishwardi upazila on the west. Main rivers are Ganges and Ichamati and noted depressions are Sonapatil Beel and Tara pasha Canal.

\section{Sample collection}

In this study, the sampling sites are located inside Pabna Sadar Upazila. Twenty (20) samples were collected from the study area. Among them ten (10) surface water samples were collected in plastic bottles from ponds, lakes and rivers and 10 (ten) soil samples $(0-15 \mathrm{~cm})$ were collected randomly in the vicinity of the surface-water sampling sites. Samples were collected by proper sampling procedure in rainy season (May, 2007) and analysis of the samples was performed around two months by using standard analytical methods. The locations of the sampling sites and sources with ID numbers are shown in Table Ia and Ib.

\section{Sample Analysis}

The physicochemical parameters, anion concentrations and heavy metal concentrations of surface water (lakes, ponds

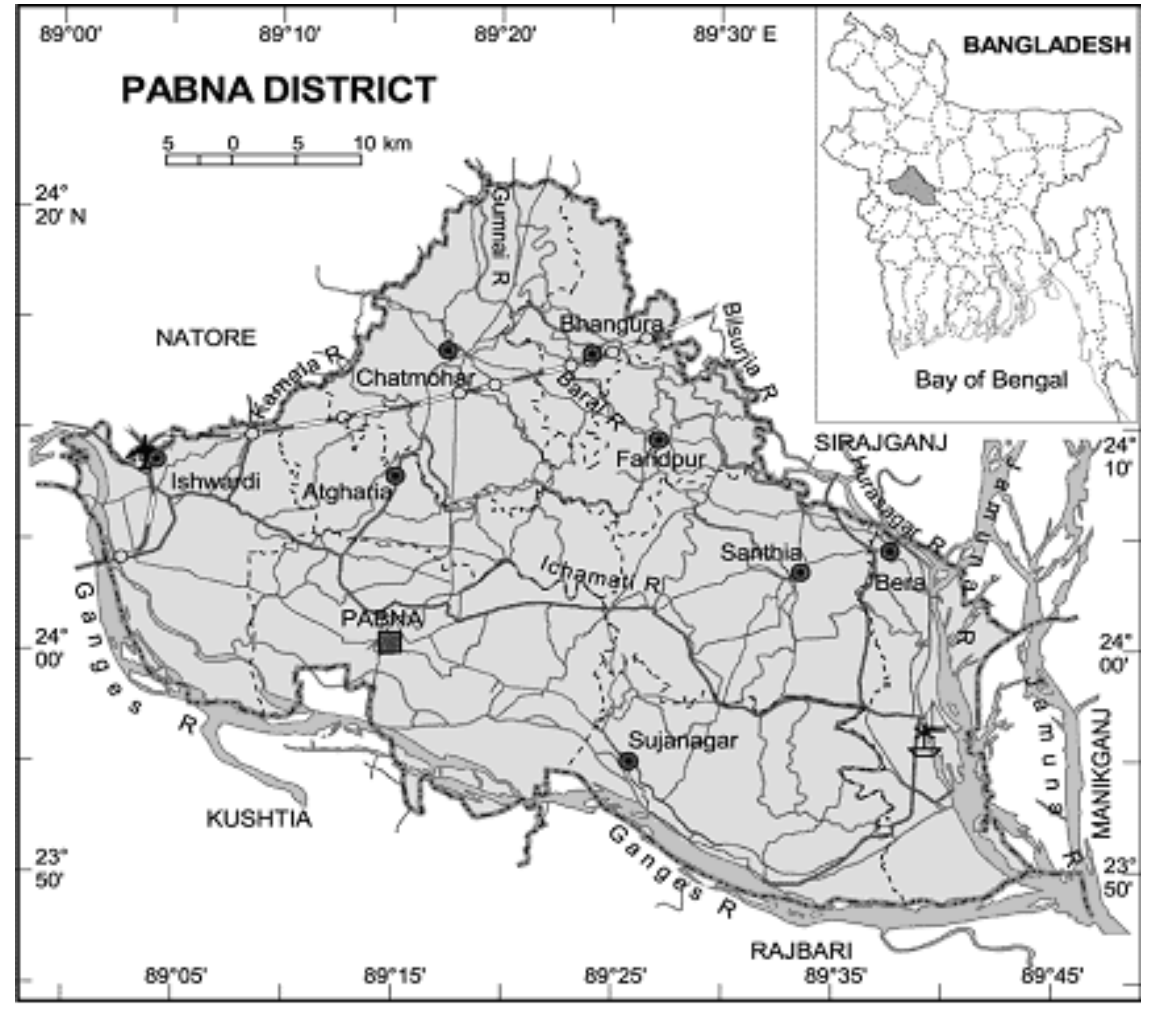

Fig. 1: The map of the study area, Pabna District. 
and rivers) samples were analyzed by different standard methods in the laboratory of analytical research division, BCSIR laboratories, Dhaka. Physicochemical parameters such as $\mathrm{pH}$, total suspended solid (TSS), total dissolved solid (TDS), electrical conductivity (EC), turbidity, dissolved oxygen (DO), biochemical oxygen demand (BOD), chemical oxygen demand (COD) of the surface water samples were measured using various standard methods (APHA, 1976). A quantitative analysis of floride $\left(\mathrm{F}^{-}\right)$, Chloride $\left(\mathrm{Cl}^{-}\right)$, Bromide $\left(\mathrm{Br}^{-}\right)$, Nitrate $\left(\mathrm{NO}_{3}{ }^{-}\right)$, Nitrite $\left(\mathrm{NO}_{2}{ }^{-}\right)$, and Sulfate $\left(\mathrm{SO}_{4}{ }^{2-}\right)$ of the surface water samples were determined by Ion Chromatography (1C). A quantitative analysis of Ammonia $\left(\mathrm{NH}_{3}\right)$ and Phosphorus $(\mathrm{P})$ of the surface water were determined by UV Spectrophotometer (Model- Lambda 25, Perkin Elmer) at $400 \mathrm{~nm}$ wave length. Phosphate $\left(\mathrm{PO}_{4}{ }^{3-}\right)$ concentration of the surface water samples was determined from phosphorus (P) concentration using the factor $(95 / 31=3.0645)($ Sultana et al., 2009) . Pb, Zn, Cd and Cu concentrations of the surface water were determined by Anodic Striping Voltammetry (AVS) and Cr, Mn, Fe, Co, Ni,
As and $\mathrm{Hg}$ were determined by Atomic Absorption Spectroscopy (AAS). The soil samples were air dried, sieved $(1 \mathrm{~mm})$ and after oven dried at $80^{\circ} \mathrm{C}$, ground to powder. After acid digestion, the residue was dissolved in dilute acid solution to yield the sample solutions. Further a quantitative analysis of heavy metals such as Chromium (Cr), Manganese ( $\mathrm{Mn})$, Iron (Fe), Cobalt (Co), Nickel (Ni), Arsenic (As), Zinc (Zn), Cadmium (Cd), Mercury (Hg) and Lead $(\mathrm{Pb})$ of the soil were determined by Atomic Absorption Flame Emission Spectrophotometer (AAS) Model: SHIMADZU, AA-6401F.

\section{Results and Discussion}

Concentrations of the physicochemical properties of the surface water samples

The concentration ranges of the physicochemical properties with the average value of the surface water of the study area are shown in Table II. The levels of pollution of the surface water were determined by comparing the observed values of

Table la: Locations and sources of the sampling sites of the surface water samples with ID numbers

\begin{tabular}{c|l|c|c}
\hline Serial No. & \multicolumn{1}{|c|}{ Sampling sites } & Sources & Sample ID \\
\hline 1 & BSCIC (Bangladesh Small \& Cottage Industries Corporation) & Pond & S-1 \\
2 & BSCIC (Bangladesh Small \& Cottage Industries Corporation) & Pond & S-2 \\
3 & Pailanpur & Pond & S-3 \\
4 & Dilalpur & Pond & S-4 \\
5 & Dilalpur & Pond & S-5 \\
6 & Baiorampur & Lake & S-6 \\
7 & Dakshin Ramchandrapur(Padmar koal) & River & S-7 \\
8 & Bangla Bazar & River & S-8 \\
9 & Dakshin Ramchandrapur(Islampur) & Lake & S-9 \\
10 & Shinga & River & S-10 \\
\hline
\end{tabular}

Table lb: Locations and sources of the sampling sites of the surface soil samples with ID numbers.

\begin{tabular}{c|l|c|c}
\hline Serial No. & \multicolumn{1}{|c|}{ Sampling sites } & Types of Soil & Sample ID \\
\hline 1 & BSCIC (Bangladesh Small \& Cottage Industries Corporation) & Uncultivated & S-1 \\
2 & BSCIC (Bangladesh Small \& Cottage Industries Corporation) & Uncultivated & S-2 \\
3 & Pailanpur & Uncultivated & S-3 \\
4 & Dilalpur & Uncultivated & S-4 \\
5 & Dilalpur & Uncultivated & S-5 \\
6 & Baiorampur & Irrigated & S-6 \\
7 & Dakshin Ramchandrapur(Padmar koal) & Uncultivated & S-7 \\
8 & Bangla Bazar & Irrigated & S-8 \\
9 & Dakshin Ramchandrapur(Islampur) & Uncultivated & S-9 \\
10 & Shinga & Uncultivated & S-10 \\
\hline
\end{tabular}


the various parameters with the drinking water standards value recommended by DoE, Bangladesh (Huq, 2003).

Water $\mathrm{pH}$ influences the other properties of water body, activity of organisms, and potency of toxic substances present in the aquatic environment. The $\mathrm{pH}$ of the surface water samples was varied from 7.30 to 9.12 . The average $\mathrm{pH}$ value was found 8.23. The electric conductivity (EC) is usually used for indicating the total concentration of the ionized constituents of water. The highest electric conductance was found at $1120 \mu \mathrm{s} / \mathrm{cm}$ and the lowest electric conductance value observed was $333 \mu \mathrm{s} / \mathrm{cm}$ and the average value was found $856 \mu \mathrm{s} / \mathrm{cm}$. TDS in water mainly consist of ammonia, nitrite, nitrate, phosphate, alkalis, some acids, sulphates, metallic ions etc (Moore et al., 1960 ). The TDS values of the study area lies between $160.8 \mathrm{mg} / \mathrm{L}$ and the $624 \mathrm{mg} / \mathrm{L}$. The average value was found $423.98 \mathrm{mg} / \mathrm{L}$. Total suspended solids denote the suspended impurities present in the water. Measurement of suspended particulate matter is important, as they are responsible for pollutant transport in the aquatic environment. The TSS values of the study area lie between at $0.08 \mathrm{mg} / \mathrm{L}$ and the $92.42 \mathrm{mg} / \mathrm{L}$. The average value was found $10.29 \mathrm{mg} / \mathrm{L}$. The presence of oxygen in water is a positive sign of water but the absence of oxygen is a signal of severe pollution. The highest dissolved oxygen (DO) value of the surface water sample was found $5.6 \mathrm{mg} / \mathrm{L}$ and the lowest dissolved oxygen (DO) of the waste water observed was $3.1 \mathrm{mg} / \mathrm{L}$ and the average value was found $4.02 \mathrm{mg} / \mathrm{L}$. Salinity is an important property of industrial and in natural water it is originally conceived as a measure of the mass of dissolved salts in a given mass of solution. The highest salinity value of the surface water was found 0.5 $\mathrm{mg} / \mathrm{L}$ and the lowest salinity value observed was $0.1 \mathrm{mg} / \mathrm{L}$. The average value was found $0.37 \mathrm{mg} / \mathrm{L}$. Turbidity in water is caused by suspended and colloidal matter such as clay, silt, finely divided organic and inorganic matter, and plankton and other microscopic organisms. The highest turbidity of the surface water was found 53 NTU and the lowest Turbidity value observed was 3.83 NTU. And the average value was found 16.05 NTU.

BOD is an index of the biodegradable organics present. The BOD values of the study area lie between at $1.24 \mathrm{mg} / \mathrm{L}$ and the $3.7 \mathrm{mg} / \mathrm{L}$. The average value was found $2.27 \mathrm{mg} / \mathrm{L}$ which is ten times higher than the standard value. Chemical oxygen demand (COD) measures the oxygen required for the oxidation of mainly organic matter by a strong chemical oxidant. The COD of the surface water samples varied from 14.08 $\mathrm{mg} / \mathrm{L}$ to $103.84 \mathrm{mg} / \mathrm{L}$ and the average value was found 37.13 $\mathrm{mg} / \mathrm{L}$. It is also ten times higher than the DoE standard. It indicated that the surface water of this area contain high content of biodegradable organic materials.

\section{Concentrations of the anionic properties of the surface water samples}

The concentration ranges of the physicochemical properties with the average value of the surface water of the study area are shown in Table III .The concentration of fluoride which is an important inorganic anion of water and effluents varied from 0.57 to $2.75 \mathrm{ppm}$. The average value of the $\mathrm{F}^{-}$ione, of the surface water samples was found $2.13 \mathrm{ppm}$ which is two times higher than DoE standard. Chloride $\left(\mathrm{Cl}^{-}\right)$is an important chemical parameter to determine water quality. The $\mathrm{Cl}^{-}$ conc. of the surface water samples varied from 48.91 to $203.46 \mathrm{ppm}$ and the average value was found $161.20 \mathrm{ppm}$. The $\mathrm{NO}_{3}{ }^{-}$concentration of the surface water samples lies between $0.15 \mathrm{ppm}$ and $3.89 \mathrm{ppm}$. The average value was found $1.09 \mathrm{ppm}$. The concentration of nitrate $\left(\mathrm{NO}_{3}{ }^{-}\right)$which is one of the critical nutrients for the growth of algae and helps accelerating the eutrophication varied from 12.74 to $70.77 \mathrm{ppm}$ and the average value was found $39.84 \mathrm{ppm}$. It is also 4 times higher than DoE standard. Sulfate is an important

Table II: Descriptive statistics of the physicochemical parameters of the surface water samples

\begin{tabular}{|c|c|c|c|c|c|}
\hline Parameter & Maximum & Minimum & Mean & Std. Devi $( \pm)$ & DoE std. (ppm) \\
\hline TSS (mg/L) & 92.42 & 0.08 & 10.29 & 28.88 & \\
\hline TDS (mg/L) & 624 & 160.8 & 423.98 & 132.98 & 1000 \\
\hline Turbidity (NTU) & 53 & 3.83 & 16.05 & 15.04 & 10 \\
\hline DO $(\mathrm{mg} / \mathrm{L})$ & 5.60 & 3.10 & 4.02 & 1.01 & 6 \\
\hline $\mathrm{pH}$ & 9.12 & 7.30 & 8.33 & 0.58 & $6.5-8.5$ \\
\hline $\mathrm{EC}(\mu \mathrm{s} / \mathrm{cm})$ & 1120.00 & 333 & 856.00 & 244.99 & \\
\hline BOD (mg/L) & 3.70 & 1.24 & 2.27 & 0.71 & 0.2 \\
\hline COD $(\mathrm{mg} / \mathrm{L})$ & 103.84 & 14.08 & 37.13 & 26.25 & 4 \\
\hline Salinity(mg/L) & 0.50 & 0.10 & 0.37 & 0.12 & \\
\hline
\end{tabular}


anion imparting hardness to the water. The highest $\mathrm{SO}_{4}{ }^{2-}$ of the surface water samples was found $26.26 \mathrm{ppm}$ and the lowest was observed. And the average value was found 17.25 ppm. Phosphorus (Phosphate-phosphorus) is generally the limiting nutrient for algal growth and controls the primary productivity of water body. High levels of phosphate may originate from municipal wastewater discharges, since it is an important component of detergents. The concentration of $\mathrm{PO}_{4}{ }^{3-}$ of the surface water samples varied from 0.72 to 10.03 ppm and the average value was found 4.99. The concentration of ammonia $\left(\mathrm{NH}_{3}\right)$ of the surface water samples lie between 1.02 and $3.44 \mathrm{ppm}$ and the average value was found $1.83 \mathrm{ppm}$. It is also 3 times higher than DoE standard.
$\mathrm{Zn}$ and $\mathrm{Cd}$ concentrations were found below the minimum detection limit.

Therefore, most of the parameters such BOD, COD, $\mathrm{F}^{-}$, $\mathrm{NO}_{3}{ }^{-}, \mathrm{NH}_{3}$ and $\mathrm{Pb}$ of the surface water were found significantly higher than the DoE standard for drinking water. The result suggests that heavy metals and other pollutants pollute the surface water. So the surface water is harmful for drinking and recreational purposes.

\section{Concentrations of the heavy metals of the soil samples}

Total concentrations of the heavy metals in the soils of the various locations of the study area are shown in Fig 2. Further the range of the heavy metal concentrations with the average value of the soils of this area are shown in Table V.

Table III : Descriptive statistics of the anionic parameters of the surface water samples

\begin{tabular}{l|l|l|l|l|l}
\hline \multicolumn{1}{c|}{ Anion } & Maximum & Minimum & Mean & Std. Devi $( \pm)$ & DoE std. (ppm) \\
\hline Fluoride $\left(\mathrm{F}^{-}\right)$ & 12.75 & 0.57 & 2.13 & 3.74 & 1 \\
Chloride $\left(\mathrm{Cl}^{-}\right)$ & 203.46 & 48.91 & 161.20 & 57.24 & $150-600$ \\
Nitrite $\left(\mathrm{NO}_{2}^{-}\right)$ & 3.89 & 0.15 & 1.09 & 1.23 & \\
Nitrate $\left(\mathrm{NO}_{3}{ }^{-}\right)$ & 70.77 & 12.74 & 39.84 & 21.11 & $<1$ \\
Sulfate $\left(\mathrm{SO}_{4}^{2-}\right)$ & 26.26 & 5.52 & 17.25 & 7.96 & 400 \\
Phosphate $\left(\mathrm{PO}_{4}{ }^{3-}\right)$ & 10.03 & 0.72 & 4.99 & 2.83 & 6 \\
Ammonia $\left(\mathrm{NH}_{3}\right)$ & 3.44 & 1.02 & 1.83 & 0.72 & 0.5 \\
\hline
\end{tabular}

\section{Concentrations of the heavy metals of the surface water samples}

The concentration ranges of the heavy metals with the average value of the surface water of the study area are shown in Table IV. The average concentrations of $\mathrm{Cr}, \mathrm{Mn}, \mathrm{Fe}, \mathrm{Ni}, \mathrm{As}$, $\mathrm{Hg}$ and $\mathrm{Pb}$ of the surface water samples were found 0.0050 ppm, 0.0961 ppm, 0.265 ppm, 0.0097 ppm, 0.0078ppm, $0.00032 \mathrm{ppm}$ and $0.0626 \mathrm{ppm}$. The concentration of $\mathrm{Pb}$ in the surface water is found slightly higher than the DoE water standard. In the collected surface water samples $\mathrm{Cu}$,
Comparison of the present data with the world average soil, soil of Rajarampur and soil of Savar

In this study, the heavy metal concentrations of the soils of the study area are compared with the average concentrations of heavy metals for worldwide soils (Alina K.P.,1992), the uncultivated soils of industrial area of Savar (Sultana et al. 2003) and the soils of the same geological region, Rajarampur (Islam et al., 2000) of the present studied soil Pabna Sadar (Table VI). The average concentration of As in the studied soil samples was found $3.56 \mathrm{ppm}$, which is

Table IV: Descriptive statistics of the heavy metal concentration of the surface water samples

\begin{tabular}{l|l|l|l|l|l}
\hline \multicolumn{1}{c|}{ Metals } & Maximum & Minimum & Mean & Std. Devi( \pm ) & DoE std. (ppm) \\
\hline $\mathrm{Cr}$ & 0.0134 & 0.0002 & 0.0050 & 0.0040 & 0.05 \\
$\mathrm{Mn}$ & 0.1917 & 0.012 & 0.0961 & 0.0543 & 0.1 \\
$\mathrm{Fe}$ & 0.6551 & 0.1233 & 0.2659 & 0.1588 & $0.3-1$ \\
$\mathrm{Co}$ & 0.0388 & 0.0014 & 0.0158 & 0.0153 & 1 \\
$\mathrm{Ni}$ & 0.0301 & 0.002 & 0.0097 & 0.0102 & 0.05 \\
$\mathrm{As}$ & 0.0254 & 0.0006 & 0.0078 & 0.0076 & 0.01 \\
$\mathrm{Hg}$ & 0.0007 & 0.00001 & 0.0003 & 0.0002 & 0.05 \\
$\mathrm{~Pb}$ & 0.2319 & 0.0091 & 0.0626 & 0.0950 & \\
\hline
\end{tabular}



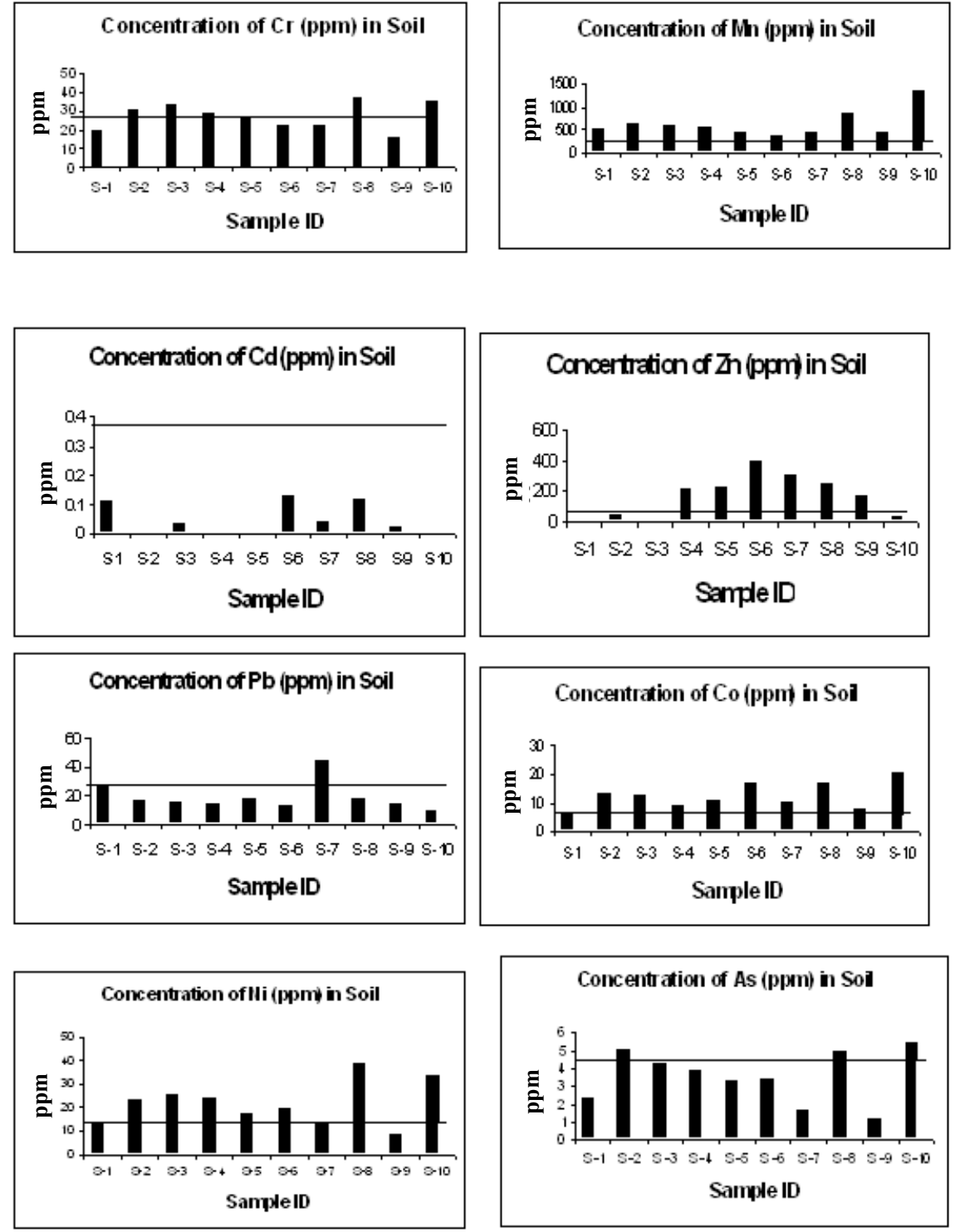

Fig. 2: The concentrations of heavy metals in the soils of the different locations of Pabna sadar. The solid line represents the world average value (Alima et al, 1992).

comparable to the data for worldwide soils, the uncultivated soils of industrial area of Savar and the soils of Rajarampr.

The average concentration of $\mathrm{Cd}$ was found $0.07 \mathrm{ppm}$ which is lower than the data for world wide soils and uncultivated soils of Savar. The average concentration of $\mathrm{Cr}$ of the soil samples was found $27.10 \mathrm{ppm}$ which is lower than the data for world wide soils, uncultivated soils of Savar and comparable to the data for the soils of Rajarampur. The average concentration of $\mathrm{Ni}$ of the soil samples was found $21.77 \mathrm{ppm}$ which is comparable to the data for worldwide soils, the uncultivated soils of industrial area. The average concentration of $\mathrm{Pb}$ of the soils was found $18.92 \mathrm{ppm}$ which is compa rable to the data of for worldwide soils, the uncultivated soils industrial area, Savar and the soils of Rajarampur. The above results suggest that the soils of this area accumulated the heavy metals like $\mathrm{As}, \mathrm{Cd}, \mathrm{Cr}, \mathrm{Ni}$ and $\mathrm{Pb}$ from the parent rocks during the soils formation process.

On the other hand, in the soil of the study area, the average value of $\mathrm{Hg}$ was found $1.84 \mathrm{ppm}$ which is around 36 times higher values than the data for worldwide soils. The average concentration of $\mathrm{Mn}$ in the studied soil was found 628.91 ppm, which is around two times higher than the data for worldwide soils. The average concentration of $\mathrm{Co}$ in the studied soils was found $12.55 \mathrm{ppm}$ which is also two times 
Table V: Descriptive statistics of the heavy metal concentrations of the soil samples

\begin{tabular}{l|l|l|l|l}
\hline Metals & Maximum & Minimum & Mean & Std. Devi $( \pm)$ \\
\hline $\mathrm{Cr}$ & 37.42 & 16.56 & 27.10 & 7.16 \\
$\mathrm{Mn}$ & 1369.99 & 389.52 & 628.91 & 292.65 \\
$\mathrm{Fe}$ & 47584.5 & 11178.7 & 25544.53 & 12410.48 \\
$\mathrm{Co}$ & 20.81 & 6.95 & 12.55 & 4.37 \\
$\mathrm{Ni}$ & 38.98 & 8.11 & 21.77 & 9.27 \\
$\mathrm{Zn}$ & 395.09 & 0.30 & 165.04 & 136.73 \\
$\mathrm{As}$ & 5.40 & 1.19 & 3.56 & 1.46 \\
$\mathrm{Cd}$ & 0.13 & 0.02 & 0.07 & 0.05 \\
$\mathrm{Hg}$ & 3.21 & 0.82 & 1.84 & 0.62 \\
$\mathrm{~Pb}$ & 44.49 & 9.33 & 18.92 & 10.04 \\
\hline
\end{tabular}

higher than the data for world wide soils. Further, the average concentration of $\mathrm{Zn}$ was found $165.04 \mathrm{ppm}$ and this value is around five times higher than the data of for worldwide soils, the uncultivated soils of industrial area Savar and the soils of Rajarampur. The higher content of heavy metals like $\mathrm{Hg}, \mathrm{Mn}, \mathrm{Co}$ and $\mathrm{Zn}$ in the soils of the study region suggests that inputs these from anthropogenic sources through irrigation, mineral fertilization, and industrial pollution, application of pesticides or waste disposal.

The above results suggest that, most of the soil contain much higher values of heavy metals than world wide average soil value and have considerable negative effects on the soil quality and agricultural crops of the area and thus harmful for human health.

\section{Conclusion}

The present study was carried out in order to assess the environmental impact of heavy metals on the surface water and soil quality of the Pabna Shadar. A total of 10 surface water samples and 10 soil samples were collected form the surrounding area of Pabna Shadar. Physicochemical parameters like $\mathrm{pH}$, TSS, TDS, EC, turbidity, DO, BOD, COD; anionic pollutants $\left(\mathrm{F}^{-}, \mathrm{Cl}^{-}, \mathrm{Br}^{-}, \mathrm{NO}_{2}{ }^{-}, \mathrm{NO}_{3}{ }^{-}, \mathrm{SO}_{4}{ }^{2-}\right.$ and $\left.\mathrm{PO}_{4}{ }^{3-}\right)$ and heavy metal ( $\mathrm{Cr}, \mathrm{Mn}, \mathrm{Fe}, \mathrm{Co}, \mathrm{Ni}, \mathrm{Cu}, \mathrm{Zn}, \mathrm{As}, \mathrm{Cd}, \mathrm{Hg}$ and $\mathrm{Pb}$ ) concentrations of the collected samples were investigated. The concentrations of the surface water samples were compared with the drinking water standard value recommended by DoE in order to assess the quality of the surface water samples of the study area. The concentrations of the soil samples were compared with the average value of worldwide soil and soils of other areas of Bangladesh. The results reveal that although few parameters of the surface water were found within the standard value of DoE, most of the physicochemical and anionic parameters such as BOD, COD, $\mathrm{F}^{-}$, $\mathrm{Mn}, \mathrm{NH}_{3}$ and $\mathrm{Pb}$ of the surface water were found significantly higher than the DoE standard for drinking water. The result suggests that the surface water of this area is polluted by various pollutants and harmful for drinking and recreational purposes. Further, most of the soil contain much higher values of heavy metals than world wide average value and have considerable negative effects on the soil quality, agricultural crops of the area and thus harmful for human health. The higher content of heavy metals like $\mathrm{Hg}, \mathrm{Mn}, \mathrm{Co}$ and $\mathrm{Zn}$ in the soils of the study region suggests that they resulted due to natural origin and anthropogenic activities like irrigation, mineral fertilization, and application of pesticides, industrial discharge.

Table VI: Comparison of the heavy metal concentrations of the soil of the study area with heavy metal concentrations of other soils

\begin{tabular}{l|c|c|c|c}
\hline Heavy metals & $\begin{array}{c}\text { Mean value of the soil of } \\
\text { Pabna Sadar (ppm) }\end{array}$ & $\begin{array}{c}\text { Average Value of the } \\
\text { world soil }(\mathrm{ppm})\end{array}$ & $\begin{array}{c}\text { Mean value of the soil } \\
\text { of Savar (ppm) }\end{array}$ & $\begin{array}{c}\text { Mean value of the } \\
\text { soil of Rajarampur (ppm) }\end{array}$ \\
\hline $\mathrm{As}$ & 3.56 & 4.40 & 7.00 & $<10$ \\
$\mathrm{Cd}$ & 0.07 & 0.37 & 0.20 & \\
$\mathrm{Co}$ & 12.55 & 5.50 & 12.00 & 33.54 \\
$\mathrm{Cr}$ & 27.10 & 0.05 & & \\
$\mathrm{Hg}$ & 1.84 & 270.00 & & 18.33 \\
$\mathrm{Mn}$ & 628.91 & 13.00 & 33.00 & 16.18 \\
$\mathrm{Ni}$ & 21.77 & 22.00 & 20.50 & 57.72 \\
$\mathrm{~Pb}$ & 18.92 & 45.00 & 60.60 & \\
$\mathrm{Zn}$ & 165.04 &
\end{tabular}

a. Analyzed by Alina et al, (1992).

b Analyzed by Sultana et al, (2003)

c. Analyzed by Islam et al., (2000). 


\section{References}

Alina P. K. and Henry P. (1992). Trace elements in Soils and Plants, 2nd ed, London CRC press.

Ali M. (1998). Lead pollution of Dhanmondi lake in Dhaka. Aqua 47, IWA publishing, Dept of Civil Engineering, Bangladesh University of Engineering and Technology (BUET), 289-296.

APHA. (1976). Standard methods for the examination of water and waste water (14thed) American Public Health Association. Washington 1193.

Bashar M. A., Waidbacher H.G. and Ullah S. M. (2005). Environmental impact assessment of industrial effluents, sewage sludges and harbour activities on river water quality, Bangladesh. J, Asiat. Soc. Bangladesh, Sci. 31(1) 1-14.

Brenner I. B. and Taylor H. E. (1992). Crit. Rev. Anal. Chem. 23: 355 .

Chamon A. S., Mondol M. N., Faiz B. Rahman H. M. and Elahi S. F. (2009). Speciation analysis of nickel in the soil of Tejgaon Industrial Area of Bangladesh, Bangladesh J. Sci. Ind. Res., 44(1): 87-108.

Chunye L., Mengechang H., Yuxiang Z., Wet G., Zhiteng Y. (2008). Distribution and contamination assessment of heavy metals in sediment of the second Songhua River China, Environ Monit Assess., 137: 329-342.

Clesceri L. S. Greenberg A. E., and Eaton A. D. (1998). Standard Methods for the Examination of water and wastewater. 20th edition, jointly published by American Public Health Association, American Water Works Association and Water Environment Federation.

Chow T. J. (1968). Water Pollution Control Federation, 40: $399-411$.

Chapman D. (1992). Water Quality Assessment, Chapman \& Hall, London, New York, Tokyo, Melbourne, Madras.

Greenland D. J. and Hayes M. H. B. (1981). The chemistry of soil processes (Eds.) John Wiley and Sons Ltd. 593-619.

Hadi D. A., Akhter S., Shafiqul A.M. and Jamaluddin M. (1997). Determination of lead, cadmium and chromium in some soil samples of Dhaka area, Bangladesh. Bangladesh J. Sci. Ind Res. 32(4): 557-560.
Huq M. E. (2003). A Compilation of Environmental Laws of Bangladesh, Administrated by the Department of Environment (DoE) 215-45.

Islam M. R. (2000). Lake and reservoir water quality affected by metals leaching from tropical soils, Bangladesh, Environmental Geology 39(10): 1083-1089.

Kashem M. A. and Singh B. R. (1998). Heavy metal contamination of soil and vegetation in the vicinity of industries in Bangladesh. Water. Air and Soil pollution. 115: 347-361.

Mahfuz M. A. A., Ahmad J. U., Sultana M. S., Rahman M. M., Goni M. A. and Rahman M. S. (2004). Status of Physico-Chemical Properties of Wastewater in Bangladesh: Case Studies in Dhalai Beel of Dhaka Export Processing Zone. Journal of Environmental Science (Dhaka), 2: 9-1.

Moore M., McLeod K. and Reed D. (1960) Fisheries: conservation propagation, $45-47$

Park P. K. and Home R. A. (1972). Water and Aqueous Solutions, Wiley-Interscience. Salmons, W. and Forstner, U. (1995). Heavy metals, Springer-Verlag Berlin Heidelberg, 2-10.

Panichayapichet P., Nitisoravut S. and Simachaya W. (2007). Spatial distribution and transport of heavy metals in soil, ponded -surface water and grass in a pb contaminated watershed as related to land use practices Environ Monit Assess., 135: 181-193.

Shamshad B. Q. and Sohela A. (2005). Study of concentration of some toxic and essential elements in marine water, sediment and their impact on marine biota. $J$. of Bangladesh Academy of Sci 29(2): 163-171.

Sultana M. S., Muramatsu Y., Rahman M. M., Rashed A., Sadat A. H. M. and Uddin M. J. (2003). Analysis of Some Trace Elements in the Uncultivated Soils of Savar by ICP-MS, Bangladesh J. of Env. Sci., 1: 57-63.

Sultana M. S., Islam M. S., Saha R and Al-Mansur M. A. (2009). Impact of the Effluents of Textile dying Industries on the Surface Water Quality inside D.N.D embankment, Narayanganj, Bangladesh J. Sci. Ind. Res., 44(1): 65-80.

Received : April 27, 2009;

Accepted : March 16, 2010 